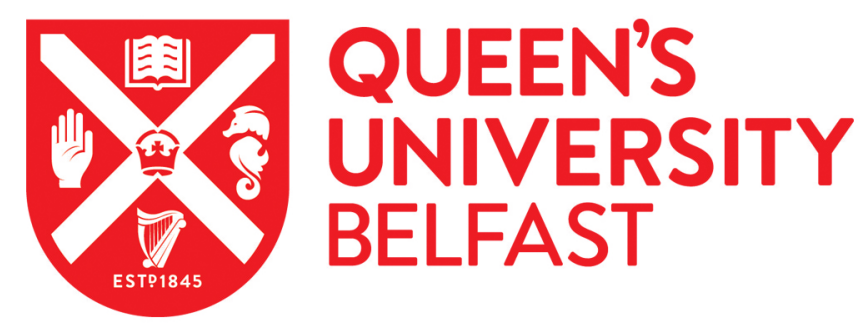

\title{
Estimation and Determinants of Phosphorus Balance and Use Efficiency of Dairy Farms in Northern Ireland: A Within and Between
} Farm Random Effects Analysis

Adenuga, A., Davis, J., Hutchinson, W. G., Donellan, T., \& Patton, M. (2018). Estimation and Determinants of Phosphorus Balance and Use Efficiency of Dairy Farms in Northern Ireland: A Within and Between Farm Random Effects Analysis. Agricultural Systems, 164, 11-19. https://doi.org/10.1016/j.agsy.2018.03.003

Published in:

Agricultural Systems

Document Version:

Peer reviewed version

Queen's University Belfast - Research Portal:

Link to publication record in Queen's University Belfast Research Portal

\author{
Publisher rights \\ Copyright 2018 Elsevier. \\ This manuscript is distributed under a Creative Commons Attribution-NonCommercial-NoDerivs License \\ (https://creativecommons.org/licenses/by-nc-nd/4.0/), which permits distribution and reproduction for non-commercial purposes, provided the \\ author and source are cited.
}

\section{General rights}

Copyright for the publications made accessible via the Queen's University Belfast Research Portal is retained by the author(s) and / or other copyright owners and it is a condition of accessing these publications that users recognise and abide by the legal requirements associated with these rights.

\section{Take down policy}

The Research Portal is Queen's institutional repository that provides access to Queen's research output. Every effort has been made to ensure that content in the Research Portal does not infringe any person's rights, or applicable UK laws. If you discover content in the Research Portal that you believe breaches copyright or violates any law, please contact openaccess@qub.ac.uk. 


\title{
Estimation and determinants of phosphorus balance and use efficiency of dairy farms in Northern Ireland: A within and between farm random effects analysis
}

\author{
Adewale Henry Adenuga ${ }^{\mathrm{a}, \mathrm{b}, \mathrm{c}, \mathrm{d}}$ John Davis ${ }^{\mathrm{a}, \mathrm{b}}$, George Hutchinson ${ }^{\mathrm{a}}$, Trevor Donnellan ${ }^{\mathrm{c}}$ and \\ Myles Patton ${ }^{b}$ \\ ${ }^{a}$ Gibson Institute for Land Food and Environment, School of Biological Sciences, Queen's \\ University Belfast, United Kingdom \\ ${ }^{\mathrm{b}}$ Agri-Food and Biosciences Institute (AFBI) Newforge Lane, Belfast, United Kingdom \\ ${ }^{\mathrm{c}}$ Teagasc, Rural Economy and Development Centre, Co Galway, Republic of Ireland \\ ${ }^{\mathrm{d} D e p a r t m e n t}$ of Agricultural Economics and Farm Management, University of Ilorin, Ilorin, \\ Nigeria \\ Corresponding Author Email: aadenuga01@qub.ac.uk
}

\section{Abstract}

The dairy sector is the most important agricultural sub-sector in Northern Ireland both in terms of size and contribution to the economy. However, the abolition of the milk quota regime in 2015 and the government's initiative for industry growth has given rise to concerns about environmental pollution, especially in terms of phosphorus $(\mathrm{P})$ balance. In light of these concerns, this study analyses the level and determinants of $P$ balance and use efficiency on Northern Ireland's dairy farms. The study employs the OECD/ EUROSTAT nutrient balance methodology and the within-between farm random effects modelling technique on a balanced panel data set. The results show that $\mathrm{P}$ balance in dairy farms in the study area is relatively high. However, the more profitable dairy farms have relatively lower P balance. We also found that the amount of grass grazed, and fertilizer price have a negative and statistically significant relationship with $\mathrm{P}$ balance, while stocking density was found to have a positive relationship with $\mathrm{P}$ balance. On the other hand, the age of the farmer and the amount of grass grazed where found to have a positive and statistically significant relationship with $\mathrm{P}$ use efficiency. The study demonstrates that increasing the percentage of grass-based feeds reduces phosphorus balance and also has a positive impact on the profitability of the dairy farms. The study recommends that farmers in the study area should increase the percentage of grass-based feeds alongside feeding concentrates with lower phosphorus contents. A moderate level of intensification should also be maintained.

Keywords: Dairy farms; Milk quota; Phosphorus balance; Random effect model

\section{Introduction}

In spite of its significance in agriculture, phosphorus $(\mathrm{P})$ has been identified as a major source of environmental pollution in Northern Ireland with about 50 per cent of farmed grassland having plant-available $\mathrm{P}$ (Olsen-P) values greater than the critical value of $25 \mathrm{mg} / \mathrm{kg}$ (Bailey, 2015; Kleinman et al., 2015, Cave and McKibbin, 2016; Smith et al, 2003). Application of $\mathrm{P}$ in excess of crop requirements results only in marginal yields increases with increased risks of loss to water bodies through run-off, erosion and leaching (Sharpley et al., 2006; Vitousek et al., 2009). P surplus accelerates eutrophication, which has a detrimental effect on biodiversity, environmental and water quality (Vitousek et al., 2009). Bailey (2016) showed that a $\mathrm{P}$ surplus above $5 \mathrm{Kg} / \mathrm{ha} /$ year increases the risk of $\mathrm{P}$ losses to water. Eutrophication of inland surface waters has been identified as a significant pollution problem in Northern Ireland (Cave and McKibbin, 2016; DOE, 2011). More than 50 per cent of all rivers in Northern Ireland are classified as "moderate/poor status". Also, about 70 per cent of lakes 
are still classed as eutrophic (with annual average $P$ concentrations in excess of $0.02 \mathrm{mg} / \mathrm{l}$, the level above which it is considered to be at risk from eutrophication) under the "water framework directive". Agriculture accounts for more than 30 per cent of the incidence of the water pollution in the region (Cave and McKibbin, 2016; Kleinman et al., 2015; "Summary of findings of Northern Ireland Nitrates", 2012). In a bid to reduce the impact of agriculture on the environment and ensure efficient use of resources, the European Union has formulated and implemented a range of agro-environmental policies to protect water quality and improve rural development (e.g. Common Agricultural Policy (CAP), EU Nitrates Directive (91/676/EEC) and the Water Framework Directive (2000/60/EC) (European Communities 2000). However, most of these policies are focused on nitrogen applications with no overarching EU regulation directly governing P application and loss from agricultural land (Amery and Schoumans, 2014). Northern Ireland is in a minority of EU countries that includes direct controls on the use of P in agriculture through the Nitrates Action Programme and Phosphorus Regulations (DAERA, 2016a). With the abolition of the milk quota regime in 2015 and an industry initiative for growth (Agri-Food Strategy Board, 2013), there are concerns that expansion in the dairy sector might pose increased environmental problems.

The gross $\mathrm{P}$ balance (GPB) is increasingly being used at farm, regional, national, and international scales to assess both the environmental impact and potential sustainability of agricultural systems (Buckley, et al., 2015; Eurostat, 2013; Gourley et al., 2007; Özbek and Leip, 2015). This approach provides an insight into the interactions between agriculture and the environment, which is useful in evaluating the impact of changes in agricultural policy (Grizzetti et al.., 2012; Öborn et al., 2003). They provide a means to estimate nutrient use efficiencies, which has been identified as an indicator of farms' agronomic performance providing insight into farms' resource use and related management decisions (Gourley et al., 2012; Oenema et al., 2003). The concern for water quality affected by P loss from agricultural land, has given rise to the need to ensure that $\mathrm{P}$ is used efficiently on farms (Cordell and Neset, 2014; Simpson et al., 2011; Weaver and Wong 2011; Amery and Schoumans, 2014).

We are not aware of any previous econometric study on $\mathrm{P}$ balance and its determinants in Northern Ireland. While a few studies on P balance have been undertaken in the Republic of Ireland (Ruane et al., 2014; Buckley et al., 2015; Mihailescu, et al., 2015), these studies are based mainly on the farm gate approach. Northern Ireland presents an interesting case study for analysing $\mathrm{P}$ balance and P use efficiency (PUE) due to the significant expansion of the dairy sector in recent years. A positive $\mathrm{P}$ balance is an indication that $\mathrm{P}$ is accumulating on agricultural land, increasing the risk of losses to the environment through leaching and runoff (Sharpley, 1994; Huhtanen et al., 2011).

The objective of this study is to estimate the P balance and use efficiency in dairy farms in Northern Ireland employing the OECD/EUROSTAT soil budget methodology. We also analysed the determinants of $\mathrm{P}$ balance and use efficiency using the Within-Between (WB) random effects modelling approach and evaluated the relationship between economic and environmental performance of dairy farms. The dairy sector is the single largest contributor to Northern Ireland's agricultural economy contributing about 30 per cent to the gross agricultural output and 42 percent of total gross margins (DAERA, 2016b). Estimating the gross $\mathrm{P}$ balance and use efficiency in the sector is essential to ensure sustainable agricultural production. The results of this study will be useful to policy makers in establishing realistic goals such as sustainable dairy expansion and mitigation of negative environmental externalities and identifying those factors that influence $\mathrm{P}$ balance and use efficiency in the region. This will give an insight into designing appropriate policy measures required to prevent environmental damage from dairy production. 


\section{Materials and methods}

\subsection{Study area}

The study was carried out in Northern Ireland (Latitude: $54^{\circ} 38^{\prime} \mathrm{N}$. Longitude: $6^{\circ} 13^{\prime} \mathrm{W}$ ) which is a part of the United Kingdom in the north-east of the island of Ireland. Agriculture is an important sector in Northern Ireland with about $74 \%$ of the total land area being devoted to it. Agriculture contributes about 3.2\% of civil employment (DAERA, 2016b). The mean annual rainfall is $1113 \mathrm{~mm}$ per year and the mean annual potential evaporation loss is $384 \mathrm{~mm}$ per year, which leaves over $700 \mathrm{~mm}$ per year of precipitation to be lost as drainage water to streams and rivers (Dairyman, 2011). The Northern Ireland landscape is dominated by two large lakes (Lough Neagh and Erne), which together drain approximately 6000 square kilometres or 40 per cent of the land area of Northern Ireland plus a further 2500 square kilometre of the Republic of Ireland (Dairyman, 2011). Figure 1 shows the map of the study area.

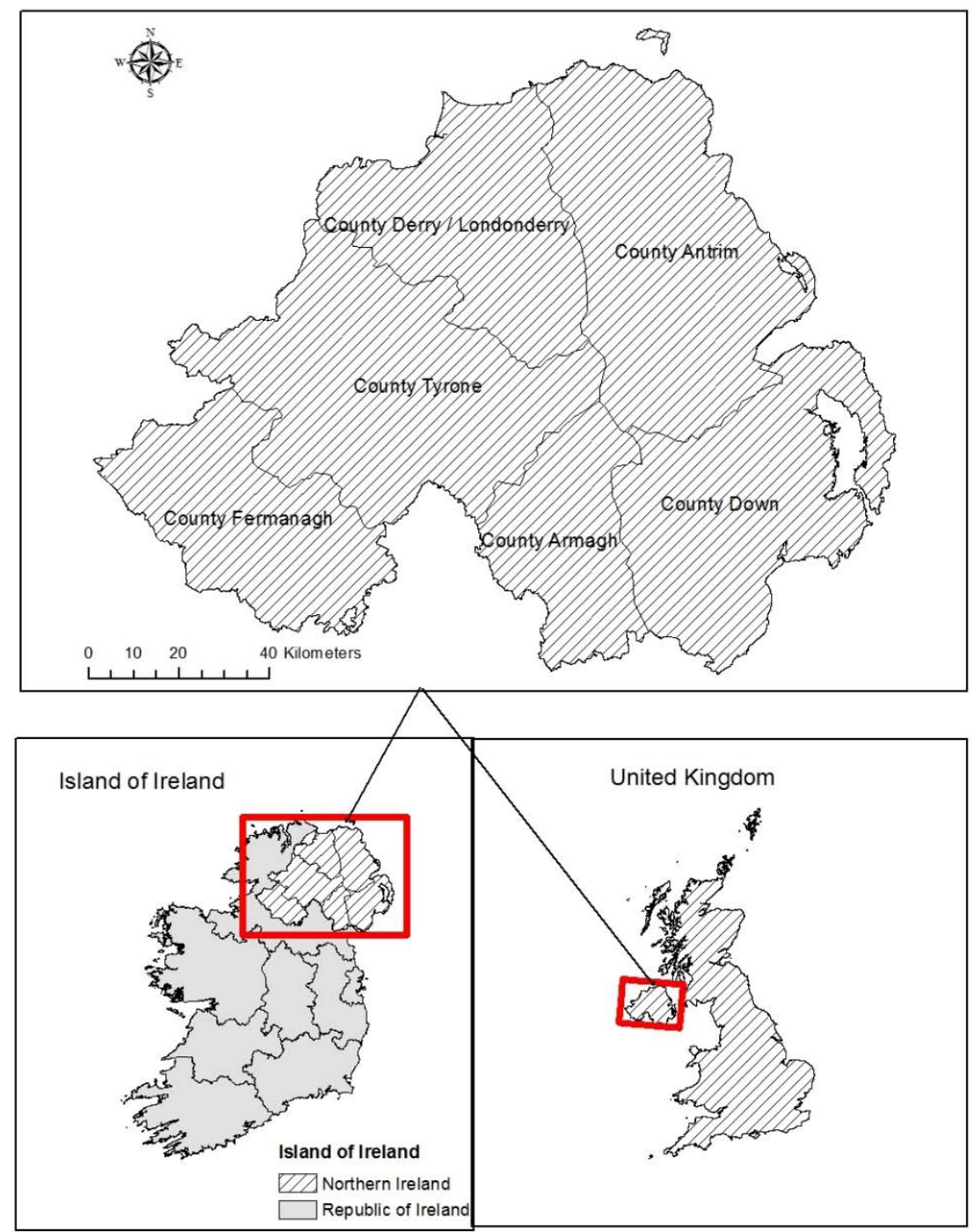

Figure 1: Map of the study area: inset is the map of United Kingdom and the Island of Ireland Source: Authors' compilation

\subsection{Sources of data}

The data set employed for this study was obtained from the Northern Ireland farm business survey (FBS, Northern Ireland). The FBS data is collected annually as part of the EU Farm 
Accountancy Data Network (FADN) requirements (FADN, 2013). A detailed set of farm accounts, environmental and enterprise level variables are recorded on a random representative sample of farms. The longitudinal nature of the data provides an opportunity to assess economic and environmental indicators over time. To achieve the objectives of this study, data on economic and environmental variables across 83 specialist dairy farms taking part in the farm survey over a period of 6 years (2009 -2014) were extracted and used for analysis. A specialist dairy farm is defined as a system where a minimum of two-thirds of farm standard output is from grazing livestock and dairy cows are responsible for a minimum of three-quarters of the grazing livestock output. Nevertheless, the specialist dairy farms also grow some crops and $\mathrm{P}$ inputs and outputs from these crops are included in the analysis.

\subsection{Analytical techniques}

The OECD/EUROSTAT methodology for estimating nutrient balances was adopted in analysing the $\mathrm{P}$ balance and use efficiency. To analyse the determinants of $\mathrm{P}$ balance and use efficiency, the within-between (WB) approach of the random effects modelling technique on a balanced panel data set (2009-2014) was employed

\subsection{Phosphorus budget methodology}

The $\mathrm{P}$ budget methodology estimates the balance between $\mathrm{P}$ input to an agricultural system and $\mathrm{P}$ output from the system expressed per hectare of agricultural land on an annual basis. Basically, two systems of estimating P balance can be distinguished based on their respective system boundaries. They are the farm-gate approach and the soil-surface balance approach. While the farm gate approach records the amounts of $\mathrm{P}$ in all kinds of inputs that enter and leave the farm through the farm-gate, the soil surface balance approach records the amounts of $P$ in all inputs and outputs that enter and leave the farm soil. That is, the amount of phosphorus used by the farm (e.g. fertilisers, animal manure), deposited from the atmosphere, and removed from the soil (in crops and through grazing). Thus, grass harvested or grazed, which is recycled internally within a farm-gate balance, must be explicitly accounted for as phosphorus removed by cutting or grazing and re-deposited as manure. Though the farm-gate approach provides better information on animal feeding efficiency, in this study we have adopted the soil surface balance approach because it gives more meaningful assessment of risk to the aquatic environment and provides more interesting information relating to the efficient use of fertilizers and animal manure on the farm (Bassanino et al., 2007; Oenema et al., 2003; Eurostat, 2013). In addition, only very few studies have adopted this approach in the context of dairy production, presumably because of the difficulty in estimating the nutrient output from grass. We are able to overcome this difficulty through the development of a novel feed requirement model which reduces the uncertainties usually associated with the soil surface balance approach.

A mathematical representation of the methodology is given in Equations (1) and (2), while Table 1 provides a summary of the variables included in the model. $\mathrm{P}$ balance is estimated as the difference between total $\mathrm{P}$ inputs and $\mathrm{P}$ uptake (output), while $\mathrm{P}$ use efficiency is estimated as the ratio of total $\mathrm{P}$ uptake (output) to the total available $\mathrm{P}$ (input) expressed as a percentage (Huhtanen et al., 2011).

$$
\begin{aligned}
& \text { GPB }(\mathrm{Kg} / \mathrm{ha})=\frac{\text { Phosphorus inputs-phophorus outputs }}{\text { Utilised agricultural area }} \\
& \text { PUE }(\%)=\frac{\text { Phosphorus output }}{\text { Phosphorus input }} * 100
\end{aligned}
$$


Table 1: Estimation of Gross Phosphorus Balance (GPB)

Terms

Inputs (Kg Phosphorus per ha)

a. Mineral Fertilizer

b. Organic fertilisers (excluding livestock manure)

c. Livestock Manure

d. Other inputs (seeds)

d. Atmospheric deposition of phosphorus compounds

\section{e. Total inputs}

\section{Outputs}

f. Crop production

g. harvested and grazed grass

h. Crop residues removed

\section{i. Total outputs}

Gross Phosphorus surplus (GPS)

Phosphorus Use Efficiency (PUE)
Quantity of organic fertilizer $(\mathrm{Kg}) * \mathrm{P}$ content

Annual average population of animals (heads) * Manure excretion coefficients (Kg P/head/year)

Kg Phosphorus per ha harvested area * Utilised agricultural area (ha)

\section{Utilised agricultural area (UAA) [ha] * P} deposition rate $(\mathrm{kg} \mathrm{P} / \mathrm{ha})$

$$
a+b+c+d
$$

Crop output (Kg of dry-matter $) * \mathrm{P}$ content $(\mathrm{kg}$
Phosphorus $/ \mathrm{Kg}$ of dry-matter $)$

quantity of pasture consumed on-farm through grazing and silage $* \mathrm{P}$ content of grass $(\mathrm{kg}$ $\mathrm{P} / \mathrm{Kg}$ of dry-matter)

Crop residues removed * $\mathrm{P}$ content $(\mathrm{kg} \mathrm{P} / \mathrm{Kg}$ of dry-matter)

$\mathrm{f}+\mathrm{g}+\mathrm{h}$

e-i

(i/ e) * 100
Farm Business Survey, Northern Ireland (2009-2014). Nitrates Action Programme (NAP) and Phosphorus Regulations 2015-2018 for Northern

Ireland

OECD and EUROSTAT Nutrient budgets methodology and handbook, and Farm Business Survey, Northern Ireland (2009-2014). Contribution is Negligible.

Contribution is Negligible

Farm Business Survey, Northern Ireland (2009-2014), Ewing, 2002, and McDonald et al., 2002

NRC, 2001, Farm Business Survey, Northern Ireland (2009-2014).

Contribution is Negligible 
$\mathrm{P}$ input from chemical fertilizer was calculated by taking into account the $\mathrm{P}$ content of fertilizers applied to land. The composition and quantities of $\mathrm{P}$ in fertilizer applied to land by farmers are recorded in the FBS data base. Manure production in Kilogram of $\mathrm{P}$ is estimated by summing up the manure production of different livestock types on the farms. For each livestock type $i$ manure $\mathrm{P}$ production ( $\mathrm{P}$ excretion) is estimated by multiplying $\mathrm{P}$ excretion coefficients which represent annual average $\mathrm{P}$ excretion per head of animal for livestock type $i$ with the annual average population of that livestock type. The excretion coefficients represent the amount of $\mathrm{P}$ in manure at the time of excretion and do not account for $\mathrm{P}$ losses after excretion (Eurostat, 2013; DAERA, 2016a). The total amount of P input to the soil from seed was estimated by multiplying the hectare of crop cultivated by the recommended seeding rates for each crop and the amount of $\mathrm{P}$ in the seed obtained from literature (Eurostat, 2013). The quantity of $\mathrm{P}$ that ends up on agricultural land as a result of atmospheric deposition was assumed to be insignificant and as such was not included in the P budget calculations (Eurostat, 2013). The $P$ from crops exported in the crop products were established from the quantities of each crop type harvested and applying a standard co-efficient (McDonald, 2002; Ewing, 2002).

Unlike previous studies, for example Loro et al., (2013) that estimated P removal from grazing based on expert judgement, we employed a feed requirement model which was able to indirectly estimate the amount of pasture consumed and therefore accommodate the differences in dairy farm management. With the methodology, the annual quantity of pasture consumed on-farm through grazing and silage was estimated based on the difference between the net energy (NE) provided by feed purchased from off the farm, (Dry matter (DM) of concentrates and forages) and the total NE requirements of livestock on the farm for milk production, pregnancy, maintenance, grazing and walking as well as body weight change (Gourley et al., 2012; NRC, 2001). Mathematical representation of the model is given in equation (3). It can be described as a back-calculation approach based on accurate description of the number of grazing animals on the farm, the area under consideration and milk production data (McCarthy et al., 2011). The total NE requirements converted to unit of feed for lactation (UFL) and adapted to local farm conditions are computed based on relevant equations published in the National Research Council publication on "nutrient requirement for dairy cattle" (NRC, 2001). It was assumed that $1 \mathrm{~kg}$ dry matter of grass equals 1 unit of feed for lactation (UFL) (McCarthy et al., 2011). Stocking rate was expressed as livestock units (LU) per hectare. The amount of nutrient output from grass was therefore obtained by multiplying by the quantity of grazed grass by the appropriate P coefficients in grass (Eurostat, 2013). This method provides a logical and quantitative framework for analysing between farm differences in productivity and pasture utilisation.

NE supplied by grass=Total NE requirements -Total NE from supplementary feed

As robustness check we also employed the farm gate approach to estimate the $\mathrm{P}$ balance and use efficiency in the dairy farms. The results can be found in the appendix A. In this case, the $\mathrm{P}$ inputs are from chemical fertilisers, concentrate and forage feeds that are imported into the farm while the $\mathrm{P}$ outputs are from milk, other livestock products and crop products that are exported from the farms. The $\mathrm{P}$ from chemical fertilizer inputs and crop products outputs were derived as already explained above while the $\mathrm{P}$ from feed inputs and milk outputs were estimated by multiplying their respective quantities with standard coefficients (McDonald et al., 2002). P exports from livestock was calculated from liveweight sales and multiplying by appropriate standard coefficients (McDonald et al., 2002). Similar approach was employed by Mihailescu et al., (2015). 


\subsection{Statistical analysis}

To analyse the determinants of $\mathrm{P}$ balance and use efficiency we employed the withinbetween (WB) farm random effect econometric modelling approach on a balanced panel data set (2009-2014). Panel data modelling which is based on repeated observations on individual dairy farms allows us to isolate the effects of unobserved differences between individuals. Compared to a cross-sectional or time-series modelling data, panel data has more variability and allow for the exploration of more issues (Kennedy, 2008). The within-between (WB) farm random effect econometric modelling approach is more attractive and outperforms the Random (RE) or Fixed (FE) effects models that are normally used to analyse panel and time series data in the economics and social science literature (Dieleman and Templin, 2014; Bell and Jones, 2015). This is because unlike the RE and FE models, it explicitly models the within (time) and between (individual) effects in a single model of the RE modelling framework producing smaller absolute errors and within estimates of time variant variables (Bell and Jones, 2015; Mela et al., 2016; Schunck, 2013; Vincens and Stafström, 2015; Teachman 2011; Fairbrother 2013). The approach is flexible and does not require the assumption of exogeneity of covariates and the normality of residuals which might lead to biased results in the usual RE models (Mundlak, 1978; Snijders and Bosker 2011; Bell and Jones, 2015).

Each time-varying covariate in a model is made up of two parts: one that is specific to the higher-level entity (in our case the individual farmers) and does not vary between occasions (time), and one that represents the difference between occasions. To understand this concept, let's consider the linear case of the random effect model given in equation (4)

$y_{j t}=\beta_{0}+\beta_{1} x_{j t}+\beta_{2} z_{j}+\mu_{j}+\varepsilon_{j t}$

'Where $y_{\mathrm{jt}}$ is the dependent variable for individual farm $\mathrm{j}$ at time $\mathrm{t}$, which in this case is the $\mathrm{P}$ balance or use efficiency, subscript $\mathrm{j}$ denotes the individual dairy farmer, $x_{j t}$ is a level 1 variable for individual farm $\mathrm{j}$ at time $\mathrm{t}$ that varies over time within and between the dairy farmers. For example, between 2006 and 2014, a dairy farmer may have had changes in the amount of grazed grass per hectare. This model the within effect of the variable grazed grass. On the other hand, between dairy farmers, there exist differences in the amount of grazed grass per hectare. This model the between effect of the grazed grass variable. $z_{j}$ is a level 2 variable that varies only between dairy farmers and represents other time-invariant covariates. $\mu_{j}$ is the single, aggregated, unobserved group-level effect otherwise referred to as the level 2 error and the random intercept, and $\varepsilon_{j t}$ is the level 1 error term while $\beta_{0} \ldots \beta_{2}$ are the parameters to be estimated (Schunck, 2013). Mundlak (1978) suggested that a way to reconcile the FE and RE models is to approximate the individual effect as a function of the individual means of timevarying characteristics. The specification of the model is given in equation 5:

$y_{j t}=\beta_{0}+\beta_{1} x_{j t}+\gamma \bar{x}_{j}+\mu_{j}+\varepsilon_{j t}$

Where $\bar{x}_{j}$ is the group-level mean of the explanatory variables included in the model and

estimated as $\bar{x}_{j}=n^{-1} \sum_{t=1}^{n_{j}} x_{j t}$ while $\gamma$ is the 'contextual' effect which explicitly models the difference between the within and the between effect. All other variables are as earlier defined. Bell and Jones (2015) pointed out that while the Mundlak (1978) approach is similar to the within-between approach specified in equation (6), because they both convey the same information and will fit the data equally well, the within-between approach is more interpretable with respect to temporal data. The correlation between $\bar{x}_{j}$ and $\left(x_{j t}-\bar{x}_{j}\right)$ (equation 6) will be zero which can facilitate model convergence.

$$
y_{j t}=\beta_{0}+\beta_{1}\left(x_{j t}-\bar{x}_{j}\right)+\gamma \bar{x}_{j}+\beta_{2} z_{j}+\mu_{j}+\varepsilon_{j t}
$$

Where $\beta_{1}$ gives the within-effect estimate that is, the fixed-effects estimate, $\gamma$ estimates the between effect while $\beta_{2}$ is a measure the effect of level 2 variables. All other variables are as 
earlier defined. Based on literature review, a number of variables $\left(x_{j t}\right)$ were hypothesized to influence the dependent variable at the within and between level and the analysis was undertaken following the expression in equation (6). To estimate the between and within effects in one model, we first generated the cluster-specific mean of $\left(x_{j t}\right)$. The second step is to create the deviation scores, which is also known as group mean centering used to estimate the within effect. At the within level, the variables are: farm size (wfarmsize) measured by the utilised agricultural area of the farm in hectares, amount of forage consumed (wgraze) measured in $\mathrm{Kg}$ dry matter per hectare, the age of the farm manager (wagefarmer) in years, stocking densities (wstockdensity) measured in livestock units per hectare and a dummy variable for access to off-farm income (woff-farm), participation in Agri-Environmental Schemes (wenvironment) measured as a dummy variable, fertilizer prices (wfertp) measured in pounds (£) per tonnes and. The between effect variables are: farm size (bfarmsize), amount of forage consumed (bgraze), age of the farm manager (bagefarmer) and stocking densities (bstockdensity). Due to data limitation we were unable to include more variables in the model. The analysis employed the feasible generalized least squares (FGLS) using the "runmlwin" command in "Stata" (Leckie and Charlton, 2013; Bell and Jones, 2015). To ensure homogeneity of variance, the $\mathrm{P}$ balance variable was log-transformed (Tunney et al., 2010).

\section{Results and discussion}

\subsection{Production Characteristics of the Dairy Farms in Northern Ireland}

The production profile of the sample of dairy farms (2009-2014) is presented in Table 2.

Table 2: Production profile of the sample of dairy farms (2009-2014)

\begin{tabular}{llllllll}
\hline Variables & 2009 & 2010 & 2011 & 2012 & 2013 & 2014 & $\begin{array}{l}\text { Overall } \\
\text { Average }\end{array}$ \\
\hline Age of farmer (years) & 62.04 & 62.02 & 60.45 & 60.52 & 59.50 & 59.02 & 60.59 \\
Grazed grass (kg DM/ha) & 5814.13 & 5491.74 & 5694.21 & 5657.24 & 5488.71 & 5506.80 & 5608.81 \\
Stocking density (LU/ha) & 1.96 & 1.93 & 2.01 & 2.08 & 2.06 & 2.16 & 2.03 \\
Concentrates (Kg/cow) & 2053.94 & 2211.74 & 2258.32 & 2347.06 & 2540.82 & 2489.43 & 2316.89 \\
Dairy Herd size(Numbers) & 94.95 & 96.47 & 98.91 & 100.4 & 101.31 & 105.82 & 99.64 \\
Tillage area (ha) & 1.5 & 1.9 & 2.2 & 2.5 & 2.44 & 2.42 & 2.16 \\
UAA (ha) & 74.90 & 75.9 & 77.99 & 78.36 & 77.82 & 81.51 & 77.75 \\
Milk yield (litres/cow) & 5761.14 & 6261.41 & 6374.80 & 6207.17 & 6220.64 & 6518.33 & 6223.92 \\
P Fertilizer price (£ per tonne) & 244 & 238 & 316 & 308 & 305 & 300 & 234.30 \\
\hline
\end{tabular}

Source: FBS (2009-2014); own calculation

$\mathrm{LU}=$ Livestock units; UAA $=$ Utilised agricultural area; $\mathrm{DM}=$ Dry matter

The results show a slight reduction in the average age of the farmers between 2009 and 2014 with age range of between 28 and 87 years. In the same period, the amount of grass grazed in $\mathrm{Kg}$ per hectare reduced by about 5 per cent implying that much of the increase in milk yield has come from increased concentrates feeding rather than grazed grass. On the average, the amount of grass grazed per hectare is low compared to dairy farms in the Republic of Ireland (McCarthy et al., 2011). Increased proportion of grazed grass in the diet of dairy cows can 
however be achieved either by increasing the number of grazing days, employing the on-off grazing strategy during periods of wet weather and avoiding contamination of pasture during slurry spread (Teagasc, 2015; Dale et al., 2011; Sporndly, 1996). There was also an increase in the stocking density (calculated as the sum of total livestock units, that is, dairy cows, other cattle and Sheep and goats divided by total forage area) resulting mainly from increase in the number of livestock rather than a decrease in forage area of the dairy farms. The concentrates fed per livestock unit increased by about 21 per cent while the average herd size increased by about 11 percent over the 6 years period. Less than 1 percent of the total land area is used for the cultivation of tillage crops, mainly cereals. The average utilised agricultural area increased by about 9 per cent over the period ranging between 20 and 232 hectares. The average milk production in litres per dairy cow increased by about 13 per cent over the study period. This increase may be linked to the increased use of purchased concentrates and access to milk quota from other parts of the United Kingdom. Increase in the prices of phosphorus fertilizer was also observed over the study period.

\subsection{Phosphorus balance and phosphorus use efficiency}

The results of the OECD/EUROSTAT soil surface P balance (2009-2014) are presented in Table 3 . The average value of $\mathrm{P}$ balance (equation 1 ) was positive for the six years analysed. It should be made clear that $\mathrm{P}$ inputs and outputs are based on the soil surface P-balance methodology.

Table 3: Gross phosphorus balance (GPB) and phosphorus use efficiencies (PUE) (2009-2014)

\begin{tabular}{lccccccc}
\hline & 2009 & 2010 & 2011 & 2012 & 2013 & 2014 & $\begin{array}{l}\text { Overall } \\
\text { Average }\end{array}$ \\
$\begin{array}{l}\text { Inputs (Kg P/ha) } \\
\text { Livestock Manure }\end{array}$ & 24.58 & 25.25 & 25.62 & 26.48 & 27.01 & 27.39 & 26.06 \\
Chemical Fertilizer & 6.02 & 7.55 & 5.61 & 6.00 & 9.21 & 10.58 & 7.50 \\
Seed & 0.01 & 0.01 & 0.01 & 0.01 & 0.01 & 0.01 & 0.01 \\
Total inputs & 30.61 & 32.81 & 31.24 & 32.49 & 36.23 & 37.98 & 33.56 \\
Outputs (Kg P/ha) & & & & & & & \\
Grazed grass & 22.62 & 21.30 & 22.33 & 22.65 & 22.20 & 22.24 & 22.22 \\
Crops & 0.27 & 0.34 & 0.38 & 0.35 & 0.29 & 0.30 & 0.32 \\
Total outputs & 22.89 & 21.64 & 22.71 & 23.00 & 22.49 & 22.54 & 22.55 \\
GPB (Kg P/ha) & 7.72 & 11.17 & 8.53 & 9.49 & 13.74 & 15.44 & 11.02 \\
PUE (\%) & 74.78 & 65.96 & 72.7 & 70.79 & 62.08 & 59.35 & 67.61 \\
\hline
\end{tabular}

\section{Source: Own calculation}

The average $\mathrm{P}$ balance over the 6 years period was relatively high at about $11 \mathrm{Kg} / \mathrm{ha}$ with $\mathrm{P}$ from livestock manure constituting about 77 per cent of total $\mathrm{P}$ inputs. The main source of $\mathrm{P}$ 
output was from grazed grass making up about 98 per cent of total $\mathrm{P}$ outputs. This is understandable given that the farms are specialised dairy farms. It can be observed that $P$ output per hectare from grazed grass is relatively stable over the years even with increase in herd size. The reason for this is that the $\mathrm{P}$ output from grazed grass is measured on per hectare basis and just as there was increase in herd size there was also a modest increase in land area with additional feed requirement for the dairy herd being met mostly from increase in imported feeds. For example, while the average herd size increased by about 11 per cent between 2006 and 2014, the average utilised agricultural area also increased by about 9 per cent with increase in concentrate fed per livestock unit being about 21 percent (see Section 3.1). The P balance has almost doubled over the study period between 2006 and 2015. However, the P balance for 2011 was lower to that of 2010, with much of the decrease coming from lower input from chemical P fertilizer. This might be traced to higher fertilizer prices in 2011 contributing to lower P fertilizer demand (van Grinsven et al., 2012). On average more than 40 per cent of the dairy farms have a $\mathrm{P}$ balance of more than $10 \mathrm{KgP} / \mathrm{ha}$. This is of particular importance because dairy farms in Northern Ireland are not expected to exceed $10 \mathrm{Kg}$ P/ha per year to prevent ecological damage in the form of eutrophication (The Nitrates Action Programme Regulations, 2014). The increased phosphorus surplus might be as a result of increased use of concentrates accompanied with increased livestock numbers in a bid to increase milk. Studies by Humphreys et al., (2008), Salou et al., (2016) have shown that there is positive correlation between increasing milk yield and nutrient surplus and consequently eutrophication. Milk yield increase in Northern Ireland was possible even though the European Union milk quota regime was still in existence during this period, because milk quota was not binding in Northern Ireland. This is because, dairy farmers in the region had the opportunity of purchasing milk quota from other regions of the United Kingdom. The particularly higher $\mathrm{P}$ balance in recent years may also mean that the $\mathrm{P}$ regulations introduced by the government in 2006 to limit the amount of $\mathrm{P}$ inputs into farms may have lost momentum in recent years. This result is however, in contrast to that obtained by Buckley et al. (2015), Mihailescu et al., (2015) using the farm gate approach for specialised dairy farms in the Republic of Ireland in which dairy farms have experienced a decline in $\mathrm{P}$ balance in recent years. This difference might not be unconnected with the fact that milk quota had been binding in the Republic of Ireland with little increase in milk yield during the quota years. A one-way analysis of variance (ANOVA) was conducted to determine if the difference in $\mathrm{P}$ balance across years was statistically significant. The Levene's statistic (F (5, $498)=0.50, p=0.77)$ of the $\log$ transformed $P$ balance did not reject the null hypothesis that the variances are equal between years. We found a statistically significant difference in $\mathrm{P}$ balance across years as determined by the one-way $\operatorname{ANOVA}(\mathrm{F}(5,498)=5.26, \mathrm{p}=0.0001)$. The result showed an inverse relationship between $\mathrm{P}$ balance and use efficiency (Table 3 ). Higher P balance was associated with lower P use efficiency. The average P use efficiency over the six years period was about 68 per cent and declined between 2009 and 2014 from 74 per cent to 59 per cent. This result is similar to that reported by Humphreys et al. (2008).

Although the soil surface balance and farm-gate approaches yield different absolute values, the trends exhibit similar paths (appendix A). The P balance value for the farm gate approach is higher than that of the soil surface balance approach. Also, the P use efficiency is lower for the farm gate approach compared to the soil surface approach but also with similar trend. This result is in line with that obtained from previous studies in which gross nutrient balance from the farm gate approach was found to be higher than the soil surface balance approach (Kupiec and Zbierska, 2012; Bassanino et al., 2007). It can also be observed that inputs from imported feed constitute a high proportion of the total $\mathrm{P}$ inputs and results in high environmental impact. The results from our soil balance approach of estimating $\mathrm{P}$ balance is complimented by the farm gate approach and suggests that there is significant room for improvement in $\mathrm{P}$ use on 
dairy farms by reducing P from imported feeds and increasing output from graze grass

\subsection{Determinants of gross phosphorus balance and phosphorus use efficiency}

The results of the within-between random effect model analyses are presented in Table 4 . Unlike the fixed effect model, this approach is able to provide information regarding both the within- and the between farms marginal effects separately (Dieleman and Templin 2014; Bell and Jones, 2015). The two sets of coefficients represent the between and within effects of the time variant variables which are explicitly modelled. The amount of forage consumed in $\mathrm{Kg}$ dry matter per hectare, stocking density and fertilizer price, were statistically significant variables influencing both P balance and use efficiency at the "within" and "between" level. Age of the farmer was found to have a statistically significant relationship with $P$ use efficiency at the "between" level. This result supports a causal claim for their effect on P balance and P use efficiency. The significance of the variables at both the within and between levels and the relatively small standard errors justifies the adoption of the within-between approach. This is further supported by looking at the coefficient of the stocking density variable, it can be observed that the values are different at the within and between-farm level. The estimate of 1.05 (with $\mathrm{P}$ balance as the dependent variable) at the within-farms level, implies that for a given dairy farmer, $\mathrm{P}$ balance increases by $1.05 \mathrm{Kg}$ unit if stocking density increases by $1 \mathrm{LU}$. Whereas, the estimate of 0.83 at the between-farm level implies that the difference in P balance between a farmer with higher stocking density and another farmer with lower stocking density is $0.83 \mathrm{Kg} / \mathrm{ha}$. The amount of forage consumed in grazed grass had an inverse relationship with $\mathrm{P}$ balance and the estimates at both the within and between farms are similar. This implies that $1 \mathrm{Kg} / \mathrm{ha}$ increase in the amount of grass grazed will result in a $0.004 \mathrm{Kg} / \mathrm{ha}$ decline in $\mathrm{P}$ balance. It could be argued that the relationship between stocking density and P-balance is larger for 'Within farms' because there would be little change in technology/farming system on the same farm over a six-year period, while there would be greater differences in technology/farming systems 'between farms'. In contrast, perhaps the 'grazing' variable displays a similar coefficient for 'within farms' and 'Between farms' because one would expect a more linear relationship for this variable regardless of over time or between farms. Given the negative relationship between $\mathrm{P}$ balance and amount of grass grazed, it can be concluded that increasing the proportion of livestock energy requirement met from grazing will reduce the $\mathrm{P}$ balance in dairy farms.

Table 4: Within-between regression model results for determinants of GPB and PUE in Northern Ireland 


\section{GPB}

\section{PUE}

Variables

Coefficient

SE

Coefficient

SE

Within Farms

$\begin{array}{llllr}\text { Constant } & 19.7827 * * * & 4.8304 & 54.07472 & 10.5230 \\ \text { wfarmsize (ha) } & -0.0275 & 0.0417 & 0.0686 & 0.0814 \\ \text { wgraze(kg DM /ha) } & -0.0043^{* * *} & 0.0004 & 0.0113^{* * *} & 0.0007 \\ \text { wagefarmer (years) } & -0.0064 & 0.0568 & 0.0624 & 0.1136 \\ \text { wstockdensity(LU/ha) } & 1.0498^{* * *} & 0.1483 & -0.2471 * * * & 0.0426 \\ \text { woff-farm income (dummy) } & 0.6218 & 1.3909 & -1.3970 & 2.8397 \\ \text { Wenvironment (dummy) } & -2.2829 & 1.7478 & 3.9169 & 3.4966 \\ \text { wfertp (£/tonne) } & -0.0202^{*} & 0.0111 & 0.0411^{*} & 0.0242\end{array}$

Between Farms

$\begin{array}{lcccc}\text { bfarmsize (ha) } & -0.0029 & 0.0163 & 0.0095 & 0.0332 \\ \text { bgraze }(\mathrm{kg} \mathrm{dm} / \mathrm{ha}) & -0.0042^{* * *} & 0.0006 & 0.0106^{* * *} & 0.0013 \\ \text { bagefarmer (years) } & -0.0842 & 0.0604 & 0.2128^{*} & 0.1235 \\ \text { bstockdensity (LU/ha) } & 0.8301^{* * *} & 0.1175 & -0.2388^{* * * *} & 0.0366 \\ \text { Observations } & 498 & & 498 & \end{array}$

Number of Farms

83

$\mathrm{SE}=$ standard error; Statistical significance: $* * *=1$ percent, $*=10$ percent; LU $=$ Livestock units; $\mathrm{DM}=$ Dry matter; GPB $=$ Gross phosphorus balance; PUE $=$ phosphorus use efficiency

The significant and positive relationship between the amount of forage consumed in grazed grass and $\mathrm{P}$ use efficiency also implies that $\mathrm{P}$ use efficiency increases with the increase in the amount of forage consumed in grazed grass. This result is in line with that from previous studies in which environmental pressure was found to increase with intensification of milk production (Buckley et al., 2015; Powel et al., 2010). The negative and statistically significant relationship between stocking density and $\mathrm{P}$ use efficiency is an indication that efficiency of $\mathrm{P}$ use declines with an increase in stocking density. Farmers with lower livestock densities are more likely to have lower P balance and higher P use efficiency. This result is in line with that obtained by Halberg et al., (2005) which asserts that nutrient surpluses increase with increase stocking density. The fertilizer price was found to have a negative and statistically significant relationship with $\mathrm{P}$ balance. A one unit increase in fertilizer price will result in about 0.02 $\mathrm{Kg} / \mathrm{ha}$ decrease in $\mathrm{P}$ balance. Also, a positive and significant relationship was found between fertilizer price and P use efficiency. Similar results were obtained by Buckley et al., (2015) among dairy farms in the Republic of Ireland. A negative but non-statistically significant relationship was found between age and $\mathrm{P}$ balance. However, a significant and positive relationship was found between $\mathrm{P}$ use efficiency and age at the between effect level.

\subsection{Phosphorus balance variation and economic characteristics of the dairy farms}


Given the debate on the economic viability of environmentally sustainable farms, we compared alongside other characteristics, the gross margin per livestock units and the level of $\mathrm{P}$ balance of the dairy farms. We divided the farms into two groups of lower quartile (bottom 25 percent) and upper quartile (top 25 per cent) farms based on their gross margin in pounds (f) per livestock units. As shown in Table 5, the two farm types vary in their economic and structural characteristic. The results show that $\mathrm{P}$ use efficiency in dairy farms is positively correlated with economic performance with the more profitable farms having a lower $\mathrm{P}$ balance. It is important to note however, that the not so large difference in $\mathrm{P}$ balance between the two groups is a result of the fact that $\mathrm{P}$ balance is generally high in the region. A similar result was obtained by Hennessy et al., (2013) in which they assert that the top performing farms (in an economic sense) also tend to be best performing farms from an environmental sustainability perspective. This difference may be attributed to differences in livestock feeding pattern and stocking density as observed in the costs of concentrates per litre of milk produced and amount of grass grazed in $\mathrm{Kg}$ dry matter per hectare. Though the top performing farms have higher $\mathrm{P}$ fertilizer input compared to the low performing farms, nevertheless its effect on $\mathrm{P}$ balance is offset by the higher grazing regime. It was also observed that the more profitable farms are smaller both in terms of herd size and land area.

Table 5: Comparison of Economic and Environmental Performance Dairy Farms (year 2014)

\begin{tabular}{lcl}
\hline Variables & Lower Quartile Farms & Upper Quartile Farms \\
\hline Gross margin (£/Lu) & 529.06 & 1070.14 \\
Grazed grass $(\mathrm{Kg} / \mathrm{Lu})$ & 4466.14 & 5140.97 \\
Stocking density(Lu/ha) & 2.16 & 1.98 \\
Concentrates per Dairy cow $(\mathrm{Kg})$ & 2261.19 & 2094.04 \\
Dairy Herd size & 120.41 & 90.46 \\
Tillage area (ha) & 2.0 & 4.1 \\
UAA (ha) & 91.66 & 79.10 \\
Milk yield(litres/hectare) & 8712.97 & 8838.76 \\
Milk yield (litres/cow) & 5904 & 6895 \\
Concentrate cost (£/litre) & 0.17 & 0.12 \\
Chemical fertilizer usage(Kg/ha) & 9.34 & 10.39 \\
Gross phosphorus balance $(\mathrm{Kg} / \mathrm{ha})$ & 14.11 & 13.23 \\
Phosphorus use efficiencies $(\%)$ & 65.26 & 67.32 \\
\hline
\end{tabular}

Source: Own calculation; $\mathrm{Lu}=$ Livestock units

These results further buttress the significance of the amount of grass grazed and stocking density on $\mathrm{P}$ balance and highlight the fact that dairy production can in actual sense be more profitable with better management of $\mathrm{P}$ use and feeding pattern. It should be emphasized that the upper and lower quartiles are the basis for classification of the dairy farms. They do not represent the upper and lower limits of the variables. Taking stocking density and concentrates costs for example, the lower values of these variables for the upper quartile class only imply that these group of farms (i.e. farms with higher gross margin per livestock units) have lower stocking density and concentrates costs. Put in another way; it means that farms with lower concentrates costs and stocking density, have higher gross margin per livestock units and as well as lower P balance.

\section{Conclusion and recommendations}


The results of this study show that $\mathrm{P}$ balance in Northern Ireland dairy farms is relatively high and could pose significant risk to water quality in the area. We must however emphasize that gross $\mathrm{P}$ balance estimated for the dairy farms gives only an indication of the potential risk to the environment and does not constitute actual risk which apart from economic and management practices is influenced by other factors. Further research in the form of soil test analysis will be required to ascertain the extent to which the high $\mathrm{P}$ balance translates into eutrophication problem for Northern Ireland. The average P balance has been on the increase in recent years. The increase can be traced to increased use of concentrates feed and chemical fertilizer accompanied with increased livestock numbers per hectare.

Our results have also shown that there is a positive relationship between economic and environmental performance in dairy farms and farms with lower P balance are in fact the more profitable. The accuracy and quality of the study results is enhanced by the representativeness of the panel data employed and novelty of the within-between random effect modelling approach used in analysing the determinants of $\mathrm{P}$ balance and use efficiency. Given the significance of grass grazed per hectare and the stocking density in the results of the withinbetween random effect model, it is recommended that farmers in the study area increase the percentage of grass-based feeds alongside feeding concentrates with lower P contents. A moderate level of intensification should also be maintained. This is in fact a win-win situation given that increasing the proportion of grazed grass in the diet of dairy cow also reduces costs of production. Efforts should also be made to ensure optimal use of concentrates feed and increase in grass productivity through improved nutrient and grazing management plan.

\section{Acknowledgements}

This study is funded by Teagasc under the Walsh Fellowship Programme. The authors are grateful to the Agri-Food and Biosciences Institute (AFBI), Northern Ireland for technical supports and the Department of Agriculture, Environment and Rural Affairs (DAERA), Policy and Economics Division, Northern Ireland, for providing access to data. Thanks also to Dr. John Bailey of (AFBI) for his technical support. We appreciate the contribution of the anonymous reviewers in improving the paper.

\section{References}

Agri Food Strategy Board. (2013). "Going for Growth: A strategic action plan in support of the Northern Ireland Agri-Food Industry." Available at: http://www.agrifoodstrategyboard.org.uk/uploads/Going\%20for\%20Growth\%20-\%2 0Web\%20Version.PDF. Retrieved $16^{\text {th }}$ August, 2016

Amery, F. and O.F. Schoumans, (2014). Agricultural phosphorus legislation in Europe. Merelbeke,Institute for Agricultural and Fisheries Research (ILVO), $45 \mathrm{p}$

Allison, P. D. 2009. Fixed Effects Regression Models. Thousand Oaks, CA: Sage.

Bailey J. S. (2016). Phosphorus Management for Sustainable Dairy Production. Paper presented at the Step to Sustainable Livestock International Conference, Bristol, United Kingdom. Page 51. Available at http://www.globalfarmplatform.org/wpcontent/uploads/2016/04/GFP-Steps-to-Sustainable-Livestock-2016-ConferenceAbstracts.pdf. Accessed $20^{\text {th }}$ September, 2017.

Bailey, J.S. (2015). Assessing the environmental risks associated with newly revised $\mathrm{P}$ application limits for farmland in NI. In: Proceedings of the Agricultural Research Forum 2015 (ed. M. McGee and Agricultural Research Forum Committee), pp. 10. 
Teagasc, Grange, Co. Meath, Ireland. ISBN: 978-1-84170-615-3.

Bassanino M, Grignani C., Sacco D., Allisiardi E. (2007). Nitrogen balances at the crop and farm-gate scale in livestock farms in Italy. Agriculture, Ecosystems and Environment 122 (2007) 282-294

Bell A. and K. Jones (2015). "Explaining Fixed Effects: Random Effects Modelling of TimeSeries Cross-Sectional and Panel Data. Political Science Research and Methods 3(1):133-153

Bomans E., Fransen K., Gobin A., Mertens J. Michiels P. Vandendriessche H., and Vogels N. (2005). Addressing phosphorus related problems in farm practice. Final report to the European Commission, Soil service of Belgium, Belgium

Buckley C., Wall D. P., Moran B., O’Neill and Murphy P. N. C. (2015). Post EU Nitrates Directive implementation: an examination of the sustainable use of phosphorus in milk production. Contributed Paper prepared for presentation at the 89th Annual Conference of the Agricultural Economics Society, University of Warwick, England 13 -15 April 2015. Available at http://ageconsearch.umn.edu/bitstream/204207/2/Cathal Buckley AES\%20paper\%2 0-\%20Cathal\%20Buckley\%20120415.pdf. Retrieved $16^{\text {th }}$ August, 2016

Cave S. and McKibbin D. (2016). River pollution in Northern Ireland: An overview of causes and monitoring systems, with examples of preventative measures. NIAR 691-15, Research and Information Service, Northern Ireland Assembly, Belfast. Available at http://www.niassembly.gov.uk/globalassets/documents/raise/publications/2016/envir onment/2016.pdf. Retrieved 15 th August, 2016.

Cordell, D. and Neset, T. S. (2014). Phosphorus vulnerability: a qualitative framework for assessing the vulnerability of national and regional food systems to the multidimensional stressors of phosphorus scarcity. Global Environ. Change 24, 108-122

Dairyman (2011). An Assessment of Regional Sustainability of Dairy Farming in Northern Ireland. Work package 1 Action 1. Available at, http://www.interregdairyman.eu/upload_mm/2/6/4/bba8dca7-6df5-41ae-ab682ae245e47a25_NI-Regional_Report_-WP1A1.pdf. 56pp. Accessed 02/06/2014

Dale A. Ferris C. Frost P. and Mayne S. (2011). The effect of applying slurry during the grazing season on dairy cow performance. Booklet 19. Agrisearch, Northern Ireland

Department of Agriculture, Environment and Rural Affairs (DAERA) (2016a): Nitrates Action Programme 2015-2018 and Phosphorus Regulations Guidance Booklet, $125 \mathrm{pp}$. Available at https://www.daerani.gov.uk/sites/default/files/publications/dard/nap-2015-2018-and-phosphorusregulations-guidance-booklet-final-may-2016.pdf. Accessed $15^{\text {th }}$ June, 2016

Department of Agriculture, Environment and Rural Affairs (DAERA) (2016b). Northern Ireland Agri-Food Sector, Key Statistics. CAP Policy, Economics and Statistics Division, Belfast, United Kingdom 16pp. Available at https://www.daerani.gov.uk/sites/default/files/publications/daera/Northern\%20Ireland\%20Agrifood $\% 20$ Sector $\% 20$ Key $\% 20$ Statistics $\% 202016 \% 20$ Final.pdf. Accessed $2^{\text {nd }}$ July, 2016.

Department of Environment (DOE) (2011). Water Pollution Incidents and Enforcement 2011. Annual Report Data. Northern Ireland Environment Agency, Northern Ireland. (no 
page number). Available at

https://www.daerani.gov.uk/sites/default/files/publications/doe/pollution-reportsincidents-and-enforcement-report-2011.pdf. Accessed $4^{\text {th }}$ July, 2016

Dieleman J. L. Templin T (2014): Random-Effects, Fixed-Effects and the within-between Specification for Clustered Data in Observational Health Studies: A Simulation Study. PLos One 9(10): 1-17 doi: info:doi/10.1371/journal.pone.0110257

European Commission, (2013). Report from the Commission to the Council and the European 524 Parliament on the implementation of the Council Directive 91/676/EEC concerning the protection of water against pollution caused by nitrates from agricultural sources based on Member State report for the period 2008-2011, p. 13.

Eurostat (2013). Nutrient Budgets - Methodology and Handbook. Version 1.02. Eurostat and OECD, Luxembourg

Fairbrother, M. (2013). 'Two Multilevel Modeling Techniques for Analyzing Comparative Longitudinal Survey Datasets'. Political Science Research and Methods 2(1):11940.

Ewing, W. N., (2002). The Feeds Directory: Commodity Products Guide, Context Publications.

Farm Accountancy Data Network (FADN) (2013). Concept of FADN. Available at http://ec.europa.eu/agriculture/rica/concept en.cfm. Accessed 10th June, 2016.

Gourley C. J. P., Aarons S. R. and Powell J. M. (2012). Nitrogen use efficiency and manure management practices in contrasting dairy production systems. Agriculture, Ecosystems and Environment 147:73-81

Gourley, C. J. P., Powell J. M., Dougherty W. J., and Weaver D. M. (2007). "Nutrient budgeting as an Approach to Improving Nutrients Management on Australian Dairy Farms." Australian Journal of Experimental Agriculture:47, pp. 1064-74.

Grizzetti B., Bouraoui F. and Aloe A. (2012), Changes of nitrogen and phosphorus loads to European seas, GlobalChange Biology, 18, 769 782, doi:10.1111/j.13652486.2011.02576.x.

Halberg N, van der Werf H, Basset-Mens C, Dalgaard R, de Boer IJM (2005). Environmental assessment tools for the evaluation and improvement of European livestock production systems. Livestock Production Science 96, 33-50

Hennessy, T., Buckley, C., Dillon, E., Donnellan, T., Hanrahan, K., Moran, B. and Ryan, M. (2013). Measuring Farm Level Sustainability with the Teagasc National Farm Survey. Teagasc, Athenry, Co. Galway. http://www.teagasc.ie/publications/2013/3042/SustainabilityReport.pdf

Huhtanen, P., Nousiainen, J. and Turtola, E. (2011). Dairy farm nutrient management model: 2. Evaluation of differentstrategies to mitigate phosphorus balance. Agricultural Systems 104, 383-391.

Humphreys J., K. O’Connell and I. A. Casey (2008). Nitrogen flows and balances in four grassland-based systems of dairy production on a clay-loam soil in a moist temperate climate. Grass and Forage Science, 63, 467-480 
Kleinman, J. A. P., Sharpley A. N., Withers J. A. P., Bergstro“m L., Johnson T. L., and Doody D. G. (2015). Implementing agricultural phosphorus science and management to combat eutrophication. AMBIO 44(Suppl. 2): 297310. doi: $10.1007 / \mathrm{s} 13280-015-0631-2$

Kennedy, P. (2008). A Guide to Econometrics, 6th ed. Malden, MA: Blackwell Publishing

Kupiec J. and Zbierska J. (2012). Comparison of Results Obtained from Different Nitrogen Balance in the Scale of a Field and a Farm. Pol. J. Environ. Stud. 21(5): 1295-1304

Lapple D. and Henessy T. (2012). The capacity to expand milk production in Ireland following the removal of milk quotas. Irish Journal of Agricultural and Food Research 51: 1-11

Leckie G. B. and Chalton C. M. J. (2013). runmlwin: A programme to run the MlwiN multilevel modelling software from within Stata. Journal of Statistical Software, 52(11):1-40

Loro P., Arzandeh M., Brewin D., Akinremi W., and Ige D. (2013). Estimating Soil Phosphorus Budgets for Rural Municipalities in Manitoba. Technical Report DOI: $10.13140 / 2.1 .5063 .3767$

McCarthy, B., Shalloo, L. and Geary, U. (2011). "The Grass Calculator”. Teagasc, Moorepark Animal and Grassland Research and Innovation centre, Fermoy, Co. Cork. http://www.agresearch.teagasc.ie/moorepark/calc/TheGrassCalculator.xls

McDonald P, Edwards R, Grenhalgh J, Morgan C. 2002. Animal Nutrition. Prentice Hall.

Mela G., Longhitano D., and Povellato A. (2016). Agricultural and non-agricultural determinants of Italian farmland values. Paper prepared for presentation at the 5 th AIEAA Conference "The changing role of regulation in the bio-based economy" 1617 June, 2016 Bologna, Italy. Available at; http://ageconsearch.umn.edu/bitstream/242327/2/AIEAA_2016_Mela_Longhitano_ Povellato.pdf

Mihailescu E., Murphy P. N. C., Ryan W., Casey I. A. And Humphreys J. (2015). Phosphorus balance and use efficiency on 21 intensive grass-based dairy farms in the South of Ireland, Journal of Agricultural Science (2015), 153, 520-537

Mundlak, Y. (1978), "On the Pooling of Time Series and Cross-Section Data”, Econometrica, 46: 69-85.

The Nitrates Action Programme Regulations (Northern Ireland) (2014). Statutory rules of Northern Ireland 2014 No. 307. Environmental protection, Northern Ireland. Available at http://extwprlegs1.fao.org/docs/pdf/uk142511.pdf

NRC - National Research Council. (2001). Nutrient Requirements of Dairy Cattle. 7th revised edition. National Academy Press. Washington. 408pp

Öborn, I., Edwards, A.C., Witter, E., Oenema, O., Ivarsson, K., Withers, P.J.A., Nilsson, S.I. and Stinzing, R.A. (2003) Element balances as a tool for sustainable nutrient management: A critical appraisal of their merits and limitations within an agronomic and environmental context. European Journal of Agronomy, 20, 211-225.

Oenema O., Kros H. and de Vries W. (2003), Approaches and uncertainties in nutrient budgets: implications for nutrient management and environmental policies, 
European Journal of Agronomy, 20, 3-16, doi:10.1016/S1161-0301(03)00067-4

Özbek F. S. and Leip A (2015). Estimating the Gross Nitrogen Budget under soil Nitrogen Stock changes: A case study for Turkey, Agriculture, Ecosystems and Environments 205:48-56

Powell, J.M., C.J.P. Gourley, C.A. Rotz, and D.M. Weaver (2010). Nitrogen use efficiency: A potential performance indicator and policy tool for dairy farms. Environ. Sci. Policy 13:217-228. doi:10.1016/j.envsci.2010.03.007

Ruane, E. M., Treacy, M., Lalor, S., Watson, C. J. and Humphreys, J. (2014). Farm-gate phosphorus balances and soil phosphorus concentrations on intensive dairy farms in the South-west of Ireland. Irish Journal of Agricultural and Food Research 53: 105119,2014

Salou, T., Le Mouël, C., and van der Werf, H. M. G. (2016) Environmental impacts of dairy system intensification: the functional unit matters!, Journal of Cleaner Production, doi: $10.1016 /$ j.jclepro.2016.05.019

Sharpley A. N.,Chapra S. C.,Wedepohl R., Sims J. T., Daniel T. C., Reddy K. R. (1994) Managing agricultural phosphorus for protection of surface waters: Issues and options. J. Environ. Qual. 23: 437-451.

Sharpley, A.N., T. Daniel, G. Gibson, L. Bundy, M. Cabrera, T. Sims, R. Stevens, J. Lemunyon, P. Kleinman, and R. Parry. (2006). Best Management Practices To Minimize Agricultural Phosphorus Impacts on Water Quality. U.S. Department of Agriculture, Agricultural Research Service, ARS-163, 50 pp. Available at http://www.caernarvon.org/Agricultural\%20BMP.pdf

Schunck, Reinhard. (2013). Within and between estimates in random-effects models: Advantages and drawbacks of correlated random effects and hybrid models. The Stata Journal, 13(1):65-76.

Simpson, R. J., Oberson, A., Culvenor, R. A., Ryan, M. H., Veneklaas, E. J., Lambers, H., Lynch, J. P., Ryan, P. R., Delhaize, E., Smith, F. A., Smith, S. E., Harvey, P. R. and Richardson, A. E. (2011). Strategies and agronomic interventions to improve the phosphorus-use efficiency of farming systems. Plant and Soil 349, 89-120

Smith R. V., Lennox S. D. and Bailey J. S. (2003). Halting the upward trend in soluble phosphorus transported from a grassland catchment. Journal of Environmental Quality 32, 2334-2340.

Snijders, T.A.B., and Bosker, R.J. (2011). Multilevel Analysis. An Introduction to Basic and Advanced Multilevel Modelling (2nd Edition). London, Sage. ISBN 9781849202015

Sporndly, E. (1996). The effects of fouling on herbage intake of dairy cows on late season pasture. Acta Agriculturae Scandinavica A-Animal Science 46(3): 144-153

Summary of findings of Northern Ireland 2012 Nitrates Article 10 Report and 2011 Derogation Report (2012). Available at://www.nienvironmentlink.org/cmsfiles/policyhub/files/documentation/Freshwater /summary of findings of 2012 article 10 report 2011 derogation report final_-_april_2013.pdf. Retrieved 15th August, 2016

Teagasc (2015). Recommended grazing management and dairy herd nutrition for spring 
2015. Series No. 3. Teagasc, Republic of Ireland.

Teachman, J. (2011). Modeling repeatable events using discrete-time data: Predicting marital dissolution. Journal of Marriage and Family 73: 525-540.

Tunney H., Kirwan L., Fu W., Culleton N. \& Black A. D. (2010). Long-term phosphorus grassland experiment for beef production - impacts on soil phosphorus levels and liveweight gains. Soil Use and Management 26, 237-244.

van Grinsven H. J. M, ten Berge ., H. F. M., Dalgaard T., Fraters B., Durand P., Hart A., Hofman G., Jacobsen B. H., Lalor S. T. J., Lesschen J. P., Osterburg B., Richards K. G., Techen A. K., Vertes F., Webb J., and Willems W. J. (2012). Management, regulation and environmental impacts of nitrogenfertilization in northwestern Europe under the Nitrates Directive; a benchmark study. Biogeosciences, 9, 51435160

Vincens, N., and Stafström, M. (2015). Income Inequality, Economic Growth and Stroke Mortality in Brazil: Longitudinal and Regional Analysis 2002-2009. PLos ONE, 10(9)

Vitousek P. M., R. Naylor, T. Crews, M. B. David, L. E. Drinkwater, E. Holland, P. J. Johnes, J. Katzenberger, L. A. Martinelli, P. A. Matson, G. Nziguheba, D. Ojima, C. A. Palm, G. P. Robertson, P. A. Sanchez, A. R. Townsend and F. S. Zhang (2009). Nutrient imbalances in agricultural development. Science 324:1519-1520

Watson, C.J., Smith, R.V. and Matthews, D.L. (2007). Increase in phosphorus losses from grassland in response to Olsen-P accumulation. Journal of Environmental Quality, 36, 1452-1460.

Weaver, D. M. and Wong, M. T. F. (2011). Scope to improve phosphorus (P) management and balance efficiency of crop and pasture soils with contrasting P status and buffering indices. Plant and Soil 349, 37-54

Wooldridge, J. M. (2010). Econometric Analysis of Cross Section and Panel Data. 2nd ed. Cambridge, MA: MIT Press. 
Appendix A

Table A1: Farm gate Gross phosphorus balance (GPB) and phosphorus use efficiencies (PUE)

$\begin{array}{lllllll}2009 & 2010 & 2011 & 2012 & 2013 & 2014 & \begin{array}{l}\text { Overall } \\ \text { Average }\end{array}\end{array}$

\section{Inputs (Kg Phosphorus/ha)}

Chemical Fertilizer

$\begin{array}{lllllll}6.02 & 7.55 & 5.61 & 6.00 & 9.21 & 10.58 & 7.50\end{array}$

Feeds

$17.58 \quad 19.85$

$18.79 \quad 19.86$

$21.19 \quad 20.67$

19.65

Total inputs

$23.60 \quad 27.40$

24.40

25.8

$30.40 \quad 31.25$

27.15

Outputs (Kg P/ha)

$\begin{array}{lccccccc}\text { Milk } & 6.95 & 7.58 & 7.77 & 7.72 & 7.74 & 8.04 & 7.63 \\ \text { Crops } & 0.27 & 0.34 & 0.38 & 0.35 & 0.29 & 0.30 & 0.32 \\ \text { Livestock Exports } & 2.06 & 1.83 & 2.11 & 1.92 & 1.98 & 1.94 & 1.97 \\ \text { Total outputs } & 9.28 & 9.75 & 10.26 & 9.99 & 10.01 & 10.28 & 9.92 \\ \text { GPB (Kg P/ha) } & 14.32 & 17.65 & 14.14 & 15.87 & 20.39 & 20.97 & 17.22 \\ \text { PUE (\%) } & 39.32 & 35.58 & 42.05 & 38.63 & 32.93 & 32.90 & 36.57\end{array}$

Source: Own calculation

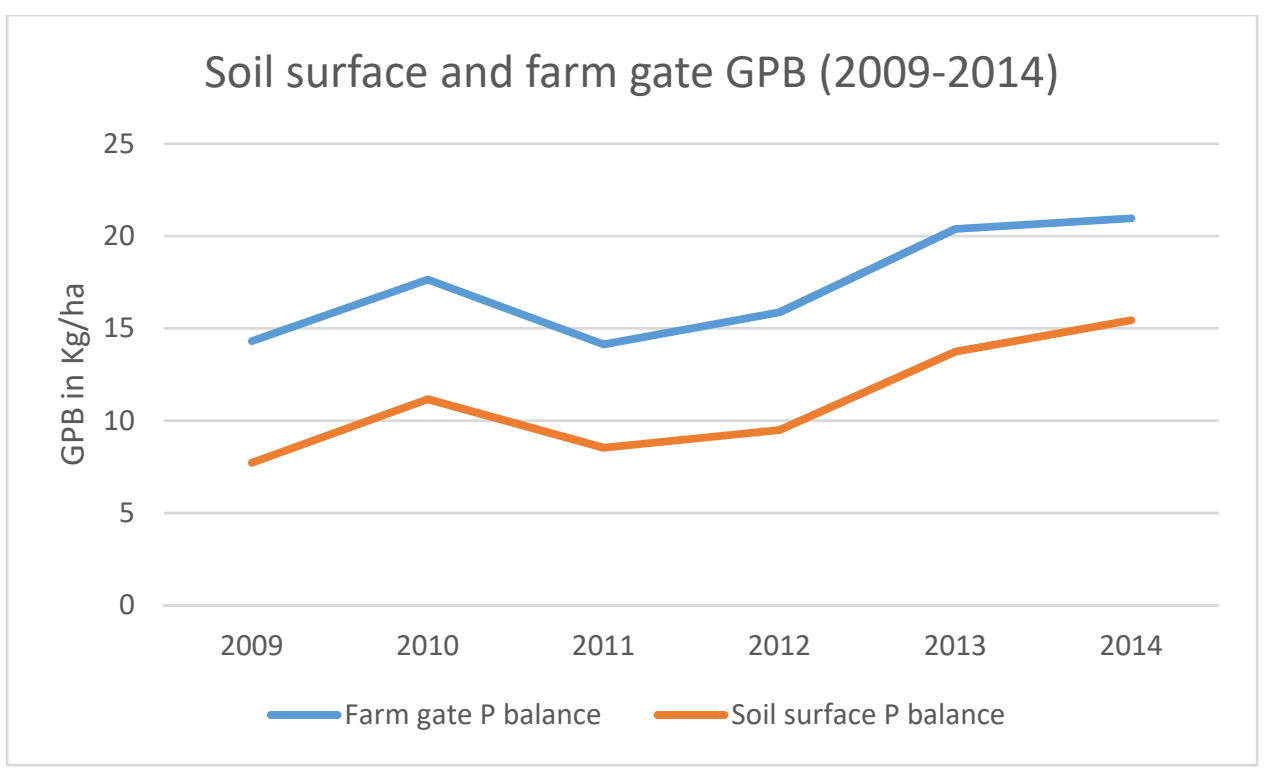

Figure A1: Graph of soil surface and farm gate GPB 


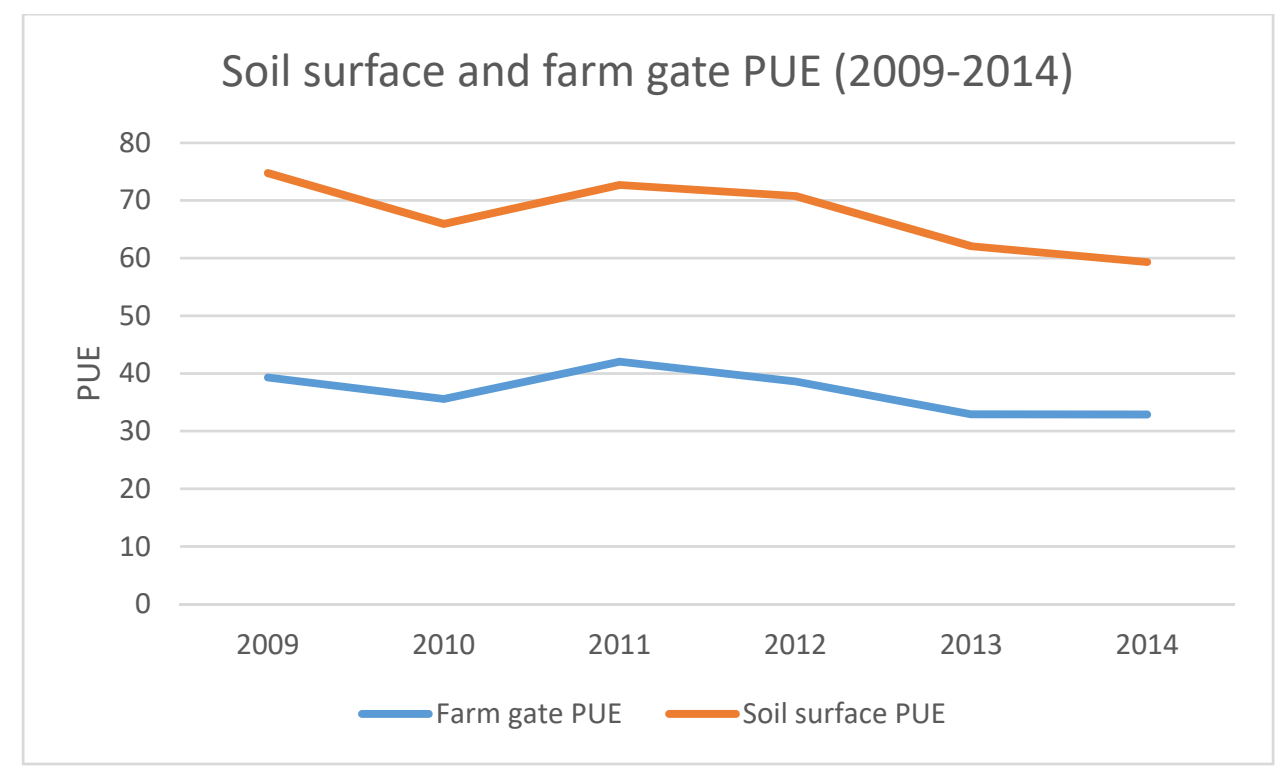

Figure A2: Graph of Soil surface and farm gate PUE 